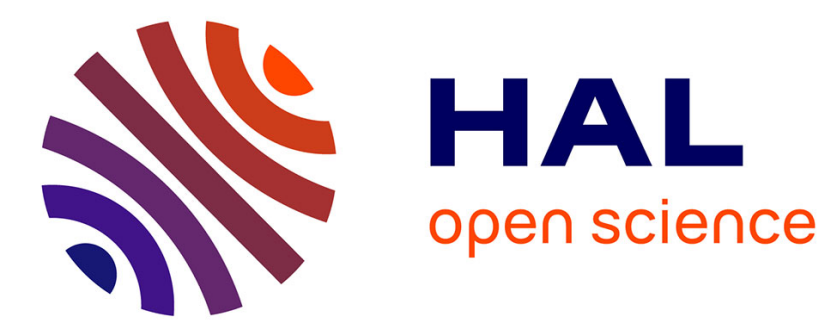

\title{
Influence of Small Addition of Ti4+ Ions on the Properties of High Permeability Ferrite
}

\author{
J. Neamtu, M. Toacsen, D. Barb
}

\section{To cite this version:}

J. Neamtu, M. Toacsen, D. Barb. Influence of Small Addition of Ti4+ Ions on the Properties of High Permeability Ferrite. Journal de Physique IV Proceedings, 1997, 07 (C1), pp.C1-79-C1-80. 10.1051/jp4:1997120 . jpa-00254850

\section{HAL Id: jpa-00254850 https://hal.science/jpa-00254850}

Submitted on 1 Jan 1997

HAL is a multi-disciplinary open access archive for the deposit and dissemination of scientific research documents, whether they are published or not. The documents may come from teaching and research institutions in France or abroad, or from public or private research centers.
L'archive ouverte pluridisciplinaire HAL, est destinée au dépôt et à la diffusion de documents scientifiques de niveau recherche, publiés ou non, émanant des établissements d'enseignement et de recherche français ou étrangers, des laboratoires publics ou privés. 


\title{
Influence of Small Addition of $\mathrm{Ti}^{4+}$ Ions on the Properties of High Permeability Ferrite
}

\author{
J. Neamtu, M.I. Toacsen* and D. Barb* \\ Institute of Microtechnology, P.O. Box 38-160, Bucharest, Romania \\ * Institute of Physics and Technology of Materials, P.O. Box M6-7, Bucharest, Romania
}

\begin{abstract}
Mn}-\mathrm{Zn}$ ferrites substituted with $\mathrm{Ti}^{4+}$ ions are now becoming commercially important. The substitution with titanium ions in $\mathrm{Mn}-\mathrm{Zn}$ ferrite is recommended for ferrites with low losses and low temperature factor of initial permeability, $\mathrm{T}_{\mathrm{k}} / \mu_{\mathrm{i}}$, because of the shift of the secondary maximum of permeability, SMP, towards lower temperatures [1] and the increase of the d.c.resistivity $[3,4,5]$.

The present paper reports the results obtained by substitution of a small amount of titamium ions to high permeability ferrite $\mathrm{Mn}_{0.51} \mathrm{Zn}_{0.43} \mathrm{Fe}^{2+}{ }_{0.06} \mathrm{Fe}_{2} \mathrm{O}_{4}$, by adequate reduction of $\mathrm{Zn}^{2+}$ content. The magnetic and electric properties improve: d.c. electrical resistivity increases while the loss factor $\operatorname{tg} \delta / \mu_{i}$ and disaccommodation decrease. By addition of $0.35 \%$ by weight $\mathrm{TiO}_{2}$, the initial permeability, at $20^{\circ} \mathrm{C}$, improves. We remark the flattening of $\mu_{\mathrm{i}}(\mathrm{T})$ curves with the increase of content of $\mathrm{Ti}^{4+}$ ions and the diminution of the peak at the Curie point, facts that can be associated with two points of anisotropy compensation instead of one, the second minimum of $\mathrm{K}_{1}$ being in the neighborhood of $\mathrm{T}_{\mathrm{c}}$. Structural and magnetic properties of high permeability ferrite with substitution of titanium ions confirm that $\mathrm{Ti}^{4+}$ ions make pairs with $\mathrm{Fe}^{2+}$ ions. $[4,6]$.
\end{abstract}

\section{INTRODUCTION}

High permeability ferrite is obtained in a relatively small percentage range of the $\mathrm{Mn}-\mathrm{Zn}$ ferrite system [2] and the raw materials must be of adequate purity, usually a total content of impurity must be $\approx 0.1 \% \mathrm{~g}[1,2$,$] . On the other hand, the$ substitution of $\mathrm{Ti}^{4+}$ ions in $\mathrm{Mn}-\mathrm{Zn}$ ferrite is recommended for the ferrite characterized by low losses and low $\mathrm{T}_{\mathrm{k}} / \mu_{\mathrm{i}}$, because of the increase of d.c.resistivity and the shift of SMP towards lower temperatures, $\sim-100^{\circ} \mathrm{C} / 1 \mathrm{~mol} \mathrm{TiO}_{2}[2,3] . \mathrm{A}$ particular feature of the substitution with titanium is that the nature of the disaccommodation process is modified, giving a pronounced improvement in the long-term stability [4]. The present paper reports the results obtained by addition of small amount of $\mathrm{TiO}_{2}(0.1-1 \%$ by weight $)$ to high permeability ferrite. For $0.35 \%$ by weight $\mathrm{TiO}_{2}$, initial permeability, at $20^{\circ} \mathrm{C}$, improves.

\section{EXPERIMENTAL}

The ferrite $\mathrm{Mn}_{0.51} \mathrm{Zn}_{0.43} \mathrm{Fe}^{2+}{ }_{0.06} \mathrm{Fe}_{2} \mathrm{O}_{4}$ and the same ferrite with the additions of $\mathrm{Ti}^{4+}$ ions were prepared by the usual ceramic technique. Appropriate mixtures of commercial oxides $\mathrm{Fe}_{2} \mathrm{O}_{3}, \mathrm{ZnO}, \mathrm{Mn}_{3} \mathrm{O}_{4}$ and $\mathrm{TiO}_{2}$ were prefired at $850^{\circ} \mathrm{C}$, milled in demineralized water and granulated. After pressing, the toroids were all sintered at $1350^{\circ} \mathrm{C}$ in air and cooled in a nitrogen atmosphere with less $0.1 \% \mathrm{O}_{2}$ [7]. For quick reference, the sample without titanium ions was denoted $\mathrm{A}$, the sample with $0.35 \% \mathrm{~g} \mathrm{TiO} 2$ was denoted $\mathrm{A}_{1}$, the sample with $0.67 \% \mathrm{~g} \mathrm{TiO}$ was denoted $\mathrm{A}_{2}$ and the sample with $1.02 \% \mathrm{~g}$ $\mathrm{TiO}_{2}$ was denoted $\mathrm{A}_{3}$. The sintered samples are in accordance with the general formula: $\mathrm{Me}^{2+}{ }_{1-x} \mathrm{Fe}^{2+}{ }_{2 x} \mathrm{Ti}^{4+}{ }_{2-2 x} \mathrm{Fe}^{3+}{ }_{2-2 x} \mathrm{O}_{4+\gamma}$ where $\mathrm{x}=0.01,0.02,0.03$. The initial permeability and relative loss factor were measured at $1-100 \mathrm{kHz}$ using a Maxwell bridge. The disaccommodation factor was obtained from the inductance change in 10 and $100 \mathrm{~min}$. after $50 \mathrm{~Hz}$ ac demagnetization. The $\mathrm{d} \mathrm{c}$ resistivity was measured with indium-gallium contacts. The initial permeability and relative loss factor (at $10 \mathrm{kHz}$ ) versus temperature within the range $-150^{\circ}-+150^{\circ} \mathrm{C}$ were measured, using a constant temperature chamber, to ensure that the samples would be in thermal equilibrium.

\section{RESULTS AND DISCUSSION}

The curves $\mu_{i}(T)$, figure la, show two characteristic phenomena. The first one is the shift of secondary maximum of permeability towards lower temperatures with the increase of titanium ions amount. The shift of SMP is approximately $-50^{\circ} \mathrm{C}$ and $-60^{\circ} \mathrm{C}$ per $1 \mathrm{~mol} \mathrm{TiO} 2$ addition. The second characteristic is the flattening of $\mu_{i}(\mathrm{~T})$ curves with the increase of $\mathrm{Ti}^{4+}$ ions. This flattening of curves could be explained by the existence of two points of anisotropy constant compensation. We remark two minimums on the tg $\delta / \mu_{i}$ vs. temperature curves (fig. 1 b) only for the samples of ferrites substituted with $\mathrm{Ti}^{4+}$ ions. These results are in accordance with the paper [5]. Stijntjes et al showed that in a material without magnetocrystalline anisotropy or at zero crossings of anizotopy, one expects a minimum of hysteresis loss and residual loss. 


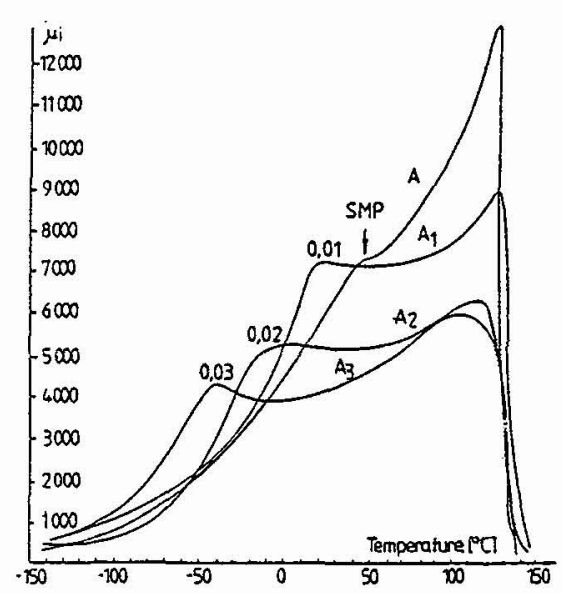

Fig.1a: Initial permeability at $10 \mathrm{kHz}$ vs. Temperature

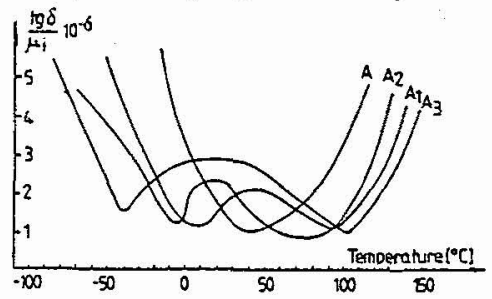

Fig.1b :Loss tangent/intial permeability vs. Temperature

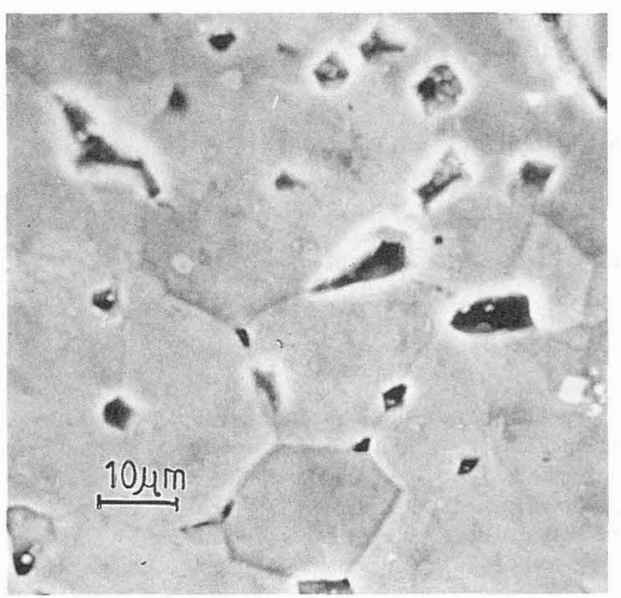

Fig.2a: $\mathrm{SEM}$ of ferrite with $0.35 \% \mathrm{~g} \mathrm{TiO}_{2}$

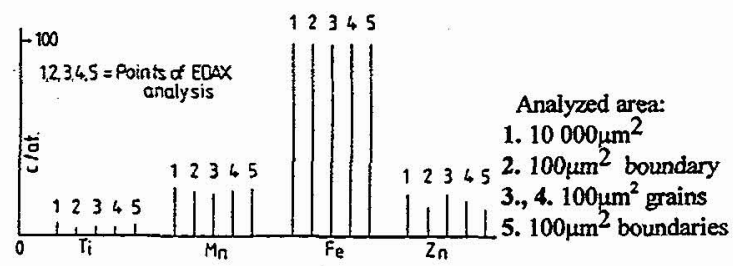

Fig.2b EDAX analysis of ferrite with $0.35 \% \mathrm{~g} \mathrm{TiO}_{2}$

Fig. $2 \mathrm{a}$ shows the microstucture of high permeability ferrite with $0.35 \% \mathrm{~g} \mathrm{TiO}_{2}$ and the concentration of the elements rated at Fe content (fig.2b). A uniform distribution of titanium ions on the surfaces of grains and boundaries is observed. The microstructure is characterized on the uniform pore-free crystallites. In the meantime, the d.c. electrical resistivity, the loss factor vs. frequency and the disaccommodation factor are improved by addition of $\mathrm{TiO}_{2}$ (Table 1 ).

Table 1

\begin{tabular}{|c|c|c|c|c|c|c|c|}
\hline Sample & $\mathrm{Ti}^{4+}$ ions & \multicolumn{4}{|c|}{$\operatorname{tg} \delta / \mu_{1} \times 10^{-6}$} & $\rho \times 10^{-2}$ & DAF $\times 10^{-6}$ \\
\hline & $(\mathbf{x})$ & $1 \mathrm{kHz}$ & $20 \mathrm{kHz}$ & $50 \mathrm{kHz}$ & $100 \mathrm{kHz}$ & {$[\Omega \mathbf{m}]$} & $\left(\right.$ at $\left.20^{\circ} \mathrm{C}\right)$ \\
\hline A & 0.00 & 1.6 & 5.0 & 18 & 32 & 15 & 4.0 \\
\hline$A_{1}$ & 0.01 & 1.5 & 3.0 & 6 & 11 & 260 & 1.2 \\
\hline$A_{2}$ & 0.02 & 2.5 & 5.0 & 8 & 12 & 500 & 0.8 \\
\hline $\mathrm{A}_{3}$ & 0.03 & 3.8 & 5.5 & 9 & 14 & 900 & 2.0 \\
\hline
\end{tabular}

\section{CONCLUSION}

This study shows that the substitution of small amount of $\mathrm{Ti}^{4+}$ ions ca- lead to the improving of magnetic properties of high permeability ferrite. The experimental da $*$ indicate that addition of $\mathrm{TiO}_{2}$, less then $0.5 \%$ by weight will yield optimum disaccommodation and temperature factor of $\mu_{\mathrm{i}}$ and reduced $i_{\mathrm{i}} \mathrm{s}$ factor $\operatorname{tg} \delta / \mu_{\mathrm{i}_{1}}$. By the addition of $0.35 \% \mathrm{~g} \mathrm{TiO} 2$, the initial permeability at room temperature increases.

The experimental results show that $\mathrm{Ti}^{4+}+\mathrm{Fe}^{2+}$ ions contribute to the anisotropy constant. $\mathrm{K}_{1}$ with a positive and weakly dependent temperature value, in good agrement with $[4,6]$. We remark the flattening of $\mu_{i}(T)$ curves with the increase of content of $\mathrm{Ti}^{4+}$ ions and the diminution of the peak at the Curie point, facts that can be associated with two points of anisotropy compensation instead of one, the second minimum of $\mathrm{K}_{1}$ being in the neighborhood of $\mathrm{T}_{\mathrm{c}}$.

\section{References}

[1] I. Hanke, Ber. Dt. Keram. Ges. 49 ,p. 295(1972)

[2] E. Röss, Proc. of ICF 1, Japan, p. 203 (1970)

[3] E. Röss, I. Hanke, Phys. Stat. Sol.(a),2, no3, p185 (1970)

[4] J. E. Knowles Philips Res. Repts. 29, p.93(1974)

[5]TG Stijntjes, J Klark and A Broese van Groenou Philips Res. Repts. 25,p. 95,(1970)

[6] J. Neamtu, V. Spanu and G. Filoti, JMMM 133, p. 481(1994)

[7] J. Neamtu PATENT No. 89003/1985 